\title{
Elektronik Hemşirelik Kayıtlarının Yapılandırılması: Sistematik Literatür İncelemesi*
}

\author{
Structuring Electronic Nursing Documentation: A Systematic Review of the Literature
}

\author{
Funda BÜYÜKYILMAZ**, Hatice KAYA**
}

İletişim/ Correspondence: Funda BÜYÜKYILMAZ Adres/ Adress: İ.Ü. Florence Nightingale Hemşirelik Fakültesi, Hemşirelik Esasları AD., Abide-i Hürriyet Cad. 34381, Şişli/ İstanbul Tel: 021244000 00/27119 E-mail: feyilmaz@istanbul.edu.tr

\begin{abstract}
$\ddot{O} Z$
Amaç: Hemşirelik kayıtları săglık bakımı kayıtlarının önemli bir parçasını oluşturmaktadır. Bu çalışma etkili ve güvenilir elektronik hemşirelik kayıtlarının yapılandırllması için mevcut literatürün sistematik incelenmesi amacıla planlandl. Yöntem: Tanımlayıcı olarak planlanan bu çalışmada MEDLINE, Scopus, PUBMED ve Cumulative Index to Nursing and Allied Health Literature (CINAHL) veri tabanlarl üzerinden "nursing documentation", "nursing records", "nursing information system”, "patient information system” anahtar kelimeleri kullanilarak, 2004-2014 tarihleri arasinda yayınlanmiss, yayın dili İngilizce olan, hakemli dergilerde yayınlanan ve tam metin erișimi bulunan 23 makale ele alındı. Bu makaleler, elektronik hemşirelik kayıtlarına ilişkin hemşirelerin görüşleri ve elektronik ortamda hemşirelik bakım planlarının kullanılması açısından incelendi.

Bulgular: Incelenen çalışmalarda, hemşirelerin elektronik hemşirelik kayıtlarının önemine inandıkları, bu kayıtların hemşirelik bakım kalitesini arttırdığını düşündükleri; buna karşın kayıt etme/ raporlandırmayı ihmal ettikleri görülmektedir. Hemşirelerin hasta öyküsü alma, hemşirelik tanısını formüle etme, amaç-girişim yazma ve değerlendirme yapmakta zorlandıkları; sıklıkla hastaların sosyo-demografik özelliklerine, tıbbi tanılarına, ve uygulanan tedavi-bakımlarının kayıt edilmesine yer verdikleri görülmektedir. Sinıflama sistemlerinden yararlanılarak elektronik bakım planlarının oluşturulmasına olumlu baktıklarl ve bu konuda yapılan ĕ̌itimlerin etkili olduğunu düşündükleri vurgulanmaktadır.

Sonuç: Bu çalışma, etkili ve güvenilir elektronik hemşirelik kayıtlarının yapılandırılmasında ve bakım planlarının oluşturulmasında mevcut durumu ortaya koymaktadır. Sinıflama sistemlerinden yararlanılarak oluşturulacak elektronik hemşirelik bilişim sistemlerinde bu bulguların dikkate alınması ve sistemi kullanacak hemşirelere gerekli ĕgitimlerin planlanması önerilir. Anahtar Kelimeler: Sağlık kayıtları, hemşirelik kayıtları, elektronik hemşirelik kayıtları.
\end{abstract}

\begin{abstract}
Aim: Nursing documentations create an important part of health care documentations. This study was designed to investigate the literature systematically to create effective and reliable electronic nursing documentation.

Method: This descriptive study was performed using keywords "nursing documentation", "nursing records", "nursing information system", "patient information system" from the databases of MEDLINE, Scopus, PUBMED, and Cumulative Index to Nursing and Allied Health Literature (CINAHL). The nursing studies selected were those published English language, from 2004-2014. 23 studies were extracted and further reviewed. These studies were examined nurse views about electronic nursing documentation and use of electronic nursing care plan.

Results: In the reviewed studies, nurses believed the importance of the electronic nursing documentation, and considered that this electronic documentation were increased quality of nursing care; but they ignored reporting. In reviewed researches, nurses slogged writing about patient history, nursing diagnosis, and outcomes-interventions; furthermore nurses often record patients' socio-demographic characteristics, medical diagnosis, cause of hospitalization, and treatment and care. In addition nurses considered positively electronic nursing documentation utilizing classification system, and education about classification was effective structuring of the nursing documentation.

Conclusion: This study concluded that current literature about electronic nursing documentation, and nursing care plan. Establishing nursing information system that include nursing classification system, takes into account these researches results and recommendation about education for nurses to use these systems.
\end{abstract}

Keywords: Health records, nursing documentation, electronic nursing documentation.

\footnotetext{
*3. Temel Hemşirelik Bakımı Kongresi’nde sözel bildiri olarak sunulmuştur (19-22 Kasım 2014, Antalya), **Doç. Dr. İstanbul Üniversitesi Florence Nightingale Hemşirelik Fakültesi
}

Yazının gönderilme tarihi: 06.05.2015

Yazının basım için kabul tarihi: 28.05.2016 


\section{GíRiş}

Değişen ve gelişen sağlık bakımı sistemi elektronik sağlık kayıtlarının kullanımını gündeme getirmiştir. Elektronik hasta kayıtlarının oluşturulması sağlık hizmetlerindeki önemli kalite göstergelerinden biridir (Akın ve Khorsid 2006; Bilgiç ve Şendir 2014; Mutluay ve Özdemir 2014). Bu kayıt sistemleri s1klıkla klinik karar destek sistemleri, tıbbi görüntü yönetim ve depolama sistemleri, hasta takip sistemleri, klinik iletişim sistemleri, akıllı kart uygulamaları, hastane bilgi sistemleri, hemşirelik kayıtlarının bilişimini içerir. $\mathrm{Bu}$ sistemler ile sağlık bakımı sonuçları için gerekli klinik verilerin elektronik olarak depolanmas1, gerektiğinde kısa sürede ulaşılabilmesi, sonuçların değerlendirilmesi ve disiplinlerarası etkili iletişim sağlanması amaçlanmaktadır (Mutluay ve Özdemir 2014; Ömürbek ve Altın 2009; Özkurt 2003).

Hemşirelik kayıtları sağlık bakımı kayıtlarının önemli bir parçasını oluşturmaktadır. Hemşireler olarak yaptığımız uygulamalar sınıflandırılmış, uluslararası kabul görmüş bir sistemin kriterlerine göre kayıt edilmez ise; yapılan iş kabul görmeyecek, hemşirelerin sağlık bakımı sistemi içindeki önemi ve değeri fark edilmeyecektir (Erdoğan 2003; Prideaux 2011). Son yıllarda hemşirelik uygulamalarını görünür hale getirmek, hemşirelerin kendi terminolojilerini kullanarak meslektaşları ile ve diğer profesyonellerle iletişim kurmalarını sağlamak için elektronik sağlık kayıtları konusunda çalışmalar başlamıştır. Bu çalışmalar sıklıkla; hemşirelik tanılarını ve girişimlerini tanımlama ve listeleme, bunları belirli kriterlere göre gruplandırma ve analiz etme, kavramların geçerliğini sağlama, ortak dil için fikir birliğine varma, maliyet hesaplama ve yönetim-denetim faaliyetleri olarak siralanabilir (Ay 2009; Bilgiç ve Şendir 2014; Erdoğan 2003; Mutluay ve Özdemir 2014). Geliştirilen elektronik kayıt sistemlerinin kullanılması ile kısa sürede hemşirelik bakım planı formları oluşturulacak, istenen verilere daha kısa sürede ulaşılabilecek ve bakıma ayrılan zaman arttırılmış olacaktır (Bilgiç ve Şendir 2014). Yapılan çalışmalarda sıklıkla hemşirelerin elektronik sağlık kayıtlarının kullanımına önem verdikleri; ancak bu konuda eğitime gereksinimleri olduğu vurgulanmaktadır (Erdemir 2007; Seçginli, Erdoğan ve Monsen 2014; Turhan ve Köse 2006).

\section{YÖNTEM}

\section{Amaç}

$\mathrm{Bu}$ çalışma etkili ve güvenilir elektronik hemşirelik kayıtlarının yapılandırılması için mevcut literatürün sistematik incelenmesi amaciyla planlandi.

Bu doğrultuda araştırmaya yön veren sorular ise;

- Hemşirelerin elektronik kayıtlara yönelik görüşleri nelerdir?

- Hemşirelerin elektronik kayıtlara yönelik uygulamaları nelerdir?

İlgili araştırmaların taranması ve seçimi: Tanımlayıcı olarak planlanan bu çalışmada MEDLINE, Scopus, PUBMED ve Cumulative Index to Nursing and Allied Health Literature (CINAHL) veri tabanları üzerinden "nursing documentation", "nursing records", "nursing information system", "patient information system" anahtar kelimeleri kullanılarak son on yılda yayınlanmış (2004-2014), yayın dili İngilizce olan, hakemli dergilerde yayınlanan ve tam metin erişimi bulunan makaleler tarandi. Bu makaleler, hemşirelerin elektronik kayıtlara yönelik görüşleri ve elektronik kayıtlara yönelik uygulamaları açısından değerlendirildi ve 23 makale inceleme kapsamına alındı. Bu konuda özel alanlarda ve spesifik konularda yapılan çalışmalar araştırma kapsamına alınmadı.

İlgili araştırma verilerinin analizi: Verilerin özetlenmesi için araştırmacılar tarafindan standart bir veri özetleme formu geliştirildi ve veriler buna göre değerlendirildi. Birbirinden bağımsız olarak araştırmacılar tarafından özetlenen veriler, daha sonra karşılaştırılarak fikir biriliğine varıldı. Veri özetleme formunda; araştırmanın türü, örneklem sayısı ve elektronik hemşirelik kayıtlarına ve elektronik ortamda hemşirelik bakım planlarının kullanılmasına ilişkin hemşirelerin görüşleri ile ilgili sonuçlara yer verildi. Bu sistematik inceleme çalışmasına dahil edilen araştırmaların türü, ölçüm yöntemleri birbirinden farklı olduğu için metaanaliz yapılmadan ilgili verilerin sunumu hedeflendi. 


\section{BULGULAR}

Bu sistematik inceleme çalışmasında, 2004-2014 yılları arasında yayınlanan 23 araştırma sonucuna yer verildi. Araştırmalar, araştırma soruları doğrultusunda iki ana başlık altında incelendi.

Hemşirelerin elektronik kayıtlara yönelik görüşlerini içeren toplam 11 araştırma değerlendirildi. $\mathrm{Bu}$ çalışmaların çoğunluğunun tanımlayıcı $(n=7)$, yarı deneysel $(n=1)$ ve kalitatif $(n=3)$ özellikte olduğu görüldü (Tablo 1). İncelenen çalışmalardan Conrad, Hanson, Hasenau, Stocker-Schneider (2012)'in yaptığı çalışmada; hemşirelerin \%98'i tıbbi kayıtların, \%86's1 ise hemşirelik kayıtlarının önemine inandığı, ancak bunların \%61'inin hasta kayıtlarını raporlandırabildiği, \%38'inin ise hemşirelik kayıtlarını ihmal ettiği belirlenmiştir. Kayıt tutmanın kolay olmaması $(\% 25,8)$, hemşirelik kayıtlarının ederinin/ geri ödemelerinin olmaması $(\% 22,6)$, kayıt etmeye yeterli zaman ayrılamaması (\%20,6), elektronik kayıtlarda hemşirelik terminolojisi hakkında bilgi eksikliğinin olması (\%38,9), kayıtlarda hemşirelik terminolojisi kullanımına alışkın olmaması $(\% 32,6)$, uygulamaların kaydedilmesinde hemşirelik terminolojisine önem verilememesi $(\% 30,4)$, elektronik kayıtlarda hemşirelik terminolojisi kullanımının zor olması (veri tabanları vb.) $(\% 28,6)$ gibi faktörlerin bu konudaki en büyük engeller olduğu vurgulanmıştır. Elektronik kayıtlarda en fazla bilinen ve kullanılan sinıflama sistemi ise NANDA-I $(\% 44,7)$ olarak saptanmıştır. Günlük çalışma zamanının \%35,8'ini hemşirelerin kayıt etmeye ayırdıkları belirlenmiştir. Lee, Mills ve Lu (2009) tarafından yapılan başka bir çalışmada ise; yapılan tıbbi kayıtların çok az oranda $(\% 24,3)$ hemşirelik bakımı ile ilgili olduğu belirtilmektedir. Ancak elektronik hemşirelik kayıt sistemlerinin kullanılmasının; bilgisayar ekranından hemşirelik tanılarının, ilişkili faktörlerin ve uygun girişimlerin seçiminin kolay olduğu, kayıt etme işleminin daha kısa sürede gerçekleşebildiği, okumayazdırma kolaylığının olduğu ve hazırlanan bakım planlarının diğer hemşireler ile tartışılarak düzenlenmesine olanak sağladığını saptamışlardır. Bunların dışında bu çalışmada, teknik sorunlar yaşanabilmesi, hemşirelik bakımından ziyade tıbbi öyküye odaklanılması, hemşire bankosunda bakım planlarının oluşturulması ve her yatak başı için bir dizüstü bilgisayar bulundurma zorunluluğu gibi olumsuz durumların da olduğunu belirtmektedir. 24 hemşire ile gerçekleştirilen kalitatif bir çalışmada da, teknik zorluklara rağmen hemşirelerin elektronik hemşirelik kayıtlarını kullanmayı denemek istedikleri, bunun önemli ve değerli olduğuna inandıkları; bu olumlu inançları ile teknolojik araçları kullanabilme yetenekleri arasındaki dengeyi de oluşturmaya çalıştıklarını belirlemişlerdir. Ayrıca hemşirelerin en önemli işlevi olan bakımın elektronik kayıtlar içinde uygun şekilde entegre edilmesi gerektiğini de vurgulamaktadır (De Vliegher ve ark. 2010) (Tablo 1).

Hemşirelerin elektronik kayıtlara yönelik uygulamalarını içeren toplam 12 araştırma değerlendirildi. Bu çalışmaların çoğunluğunun tanımlayıcı $(n=8)$, deneysel $(n=1)$ ve kalitatif ( $n=3)$ özellikte olduğu görüldü (Tablo 1). İncelenen çalışmalarda hasta kabulünden sonra planlanan hemşirelik bakımının kayıt edilmediği, hastalara uygulanan bakımların kayıt edilmediği, yapılan kayıtların büyük çoğunluğunda ise hemşire imzası bulunmadığı, kayıtlarda hastaların psiko-sosyal boyutlarına (değer ve inançlar gibi) yer verilmediği belirlenmiştir. Ayrıca yapılan kayıtlarda da tutarsızlıklar (örn. hemşirelik tanısı ile amaç, amaç ve girişimler arasında) bulunduğu, etkili bir kayıt için eğitim yapılması gerektiği önerilmektedir (Avoka-Asami ve ark. 2014; Broderick ve Coffey 2012; Paans ve ark. 2010; Stevenson ve Nilsson 2011). İnan ve Dinç (2013)'in ülkemizde yaptığı çalışmada da sıklıkla kaydedilen bakımların ağız bakımı, perine bakımı, el yıkama, yatak banyosu olduğu ve uygulanan hemşirelik bakımlarının kaydedilme oranın \%77,6 olduğu belirlenmiştir. Hemşirelik kayıtlarının kalitesinin yetersiz ve bireysel bak1mı yansıtmadığını saptamışlardır. Ayrıca bu çalışmada kayıtların zenginleştirilmesi adına eğitim ve uygulama yapılmasına gereksinim olduğu belirtilmektedir. Ofi ve Sowunmi (2012)'nin elektronik hemşirelik kayıtlarında hemşirelik sürecinin kullanımı ile ilgili çalışmasında ise; hemşirelerin hasta öyküsü, hemşirelik 


\begin{tabular}{|c|c|c|c|c|c|}
\hline 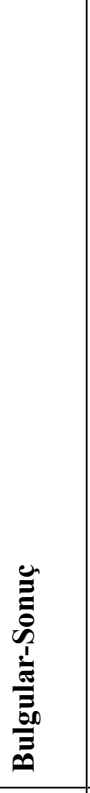 & 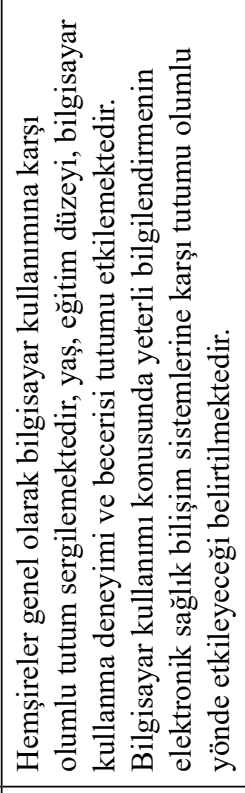 & 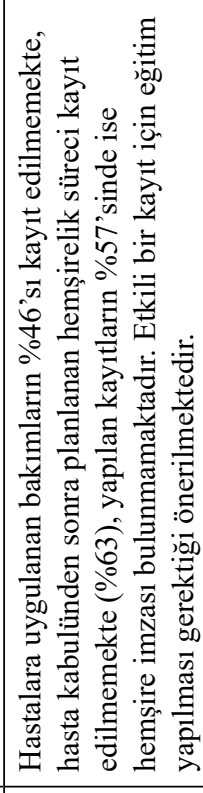 & 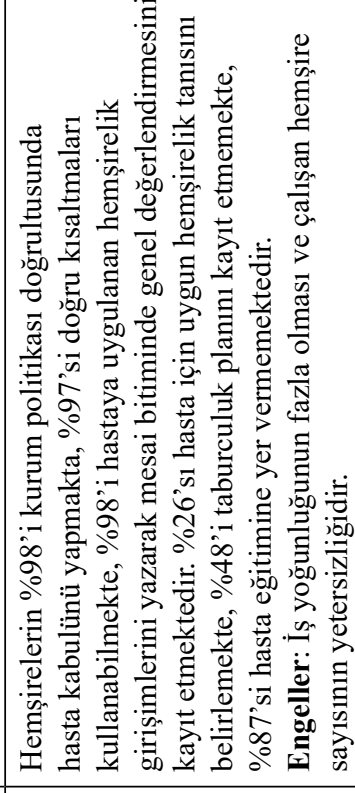 & 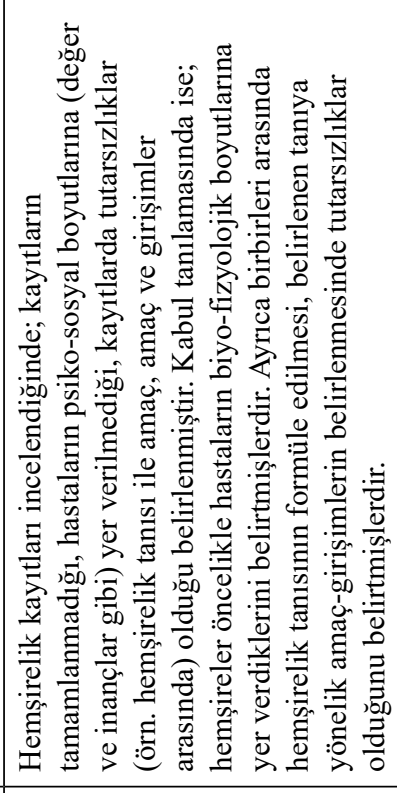 & 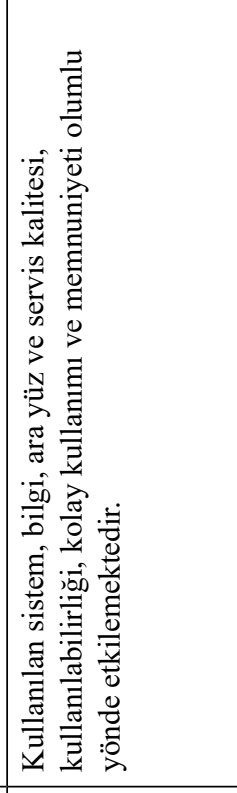 \\
\hline है & 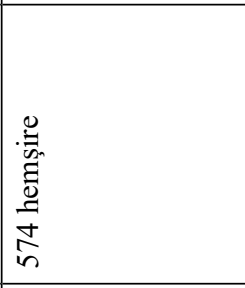 & 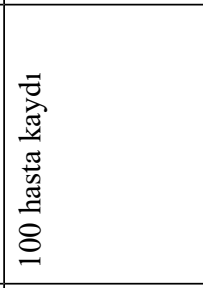 & 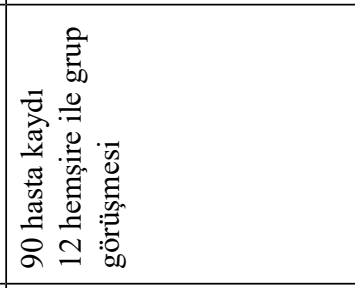 & 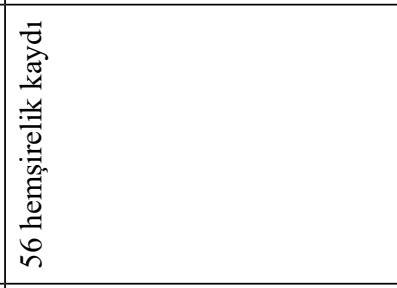 & 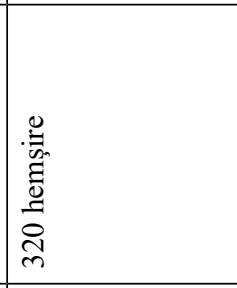 \\
\hline 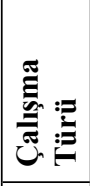 & 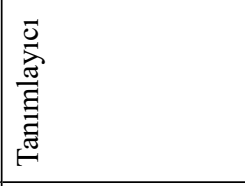 & 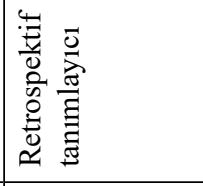 & 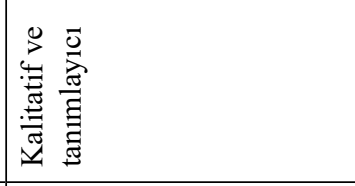 & 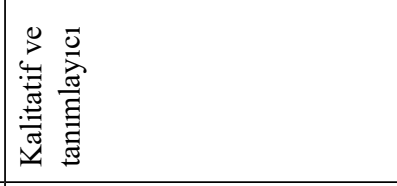 & 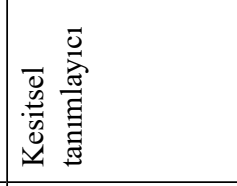 \\
\hline 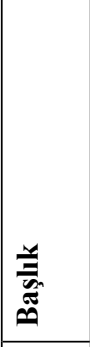 & 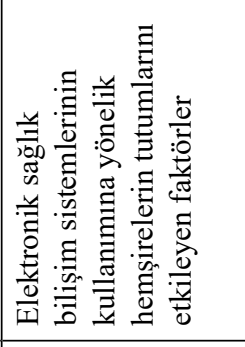 & 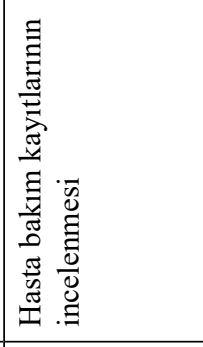 & 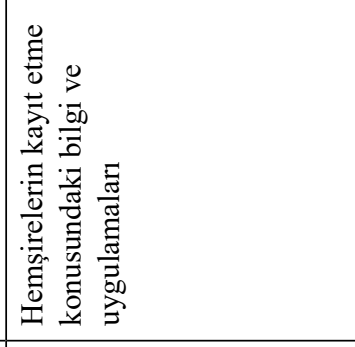 & 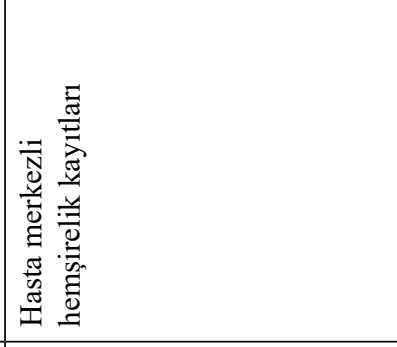 & 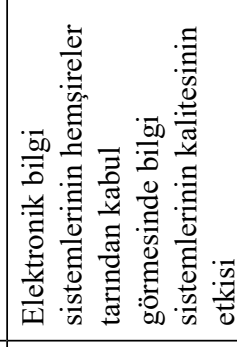 \\
\hline : & 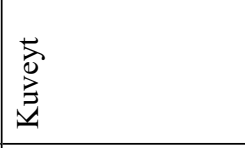 & 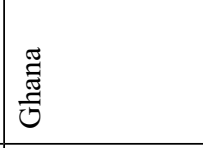 & 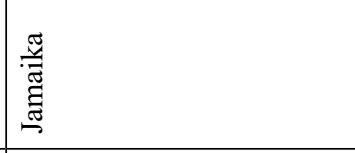 & 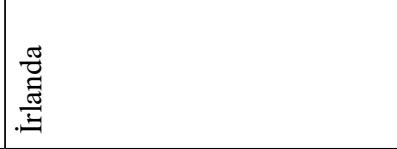 & 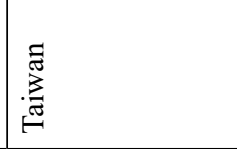 \\
\hline $\bar{\Sigma}$ & ڤે & $\stackrel{\vec{a}}{\vec{\lambda}}$ & $\stackrel{m}{\vec{\nu}}$ & 곤 & $\stackrel{\sim}{\stackrel{\sim}{*}}$ \\
\hline 莺 & 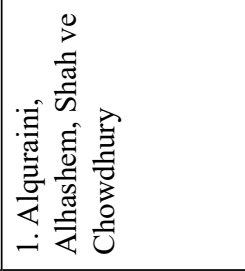 & 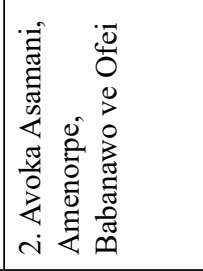 & 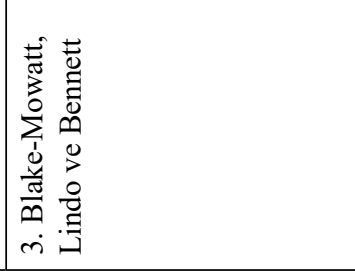 & 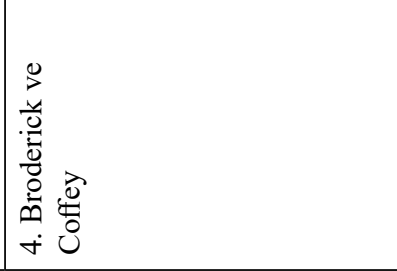 & $\begin{array}{l}\text { 步 } \\
\text { Uू } \\
\text { in } \\
\text { in }\end{array}$ \\
\hline
\end{tabular}




\begin{tabular}{|c|c|c|c|}
\hline 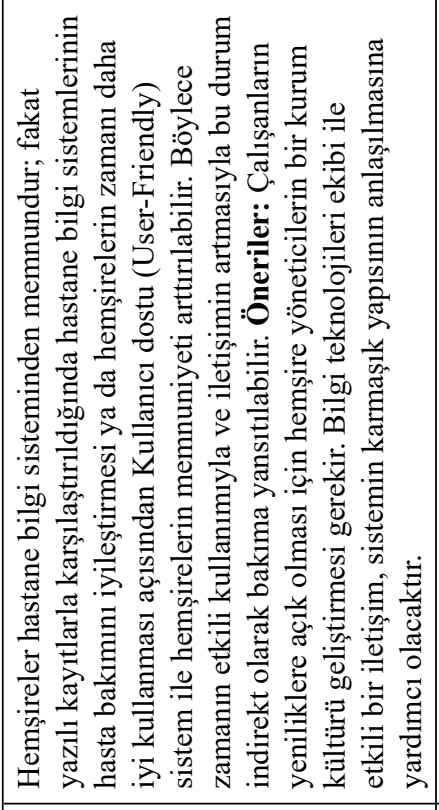 & 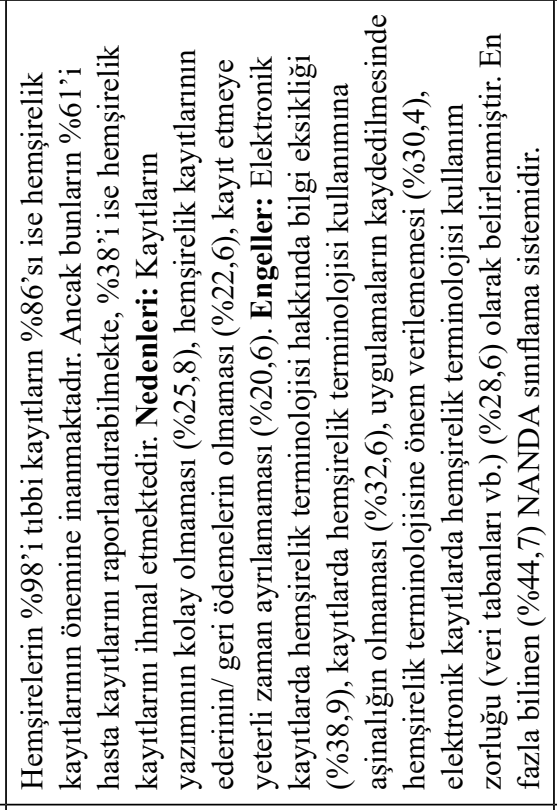 & 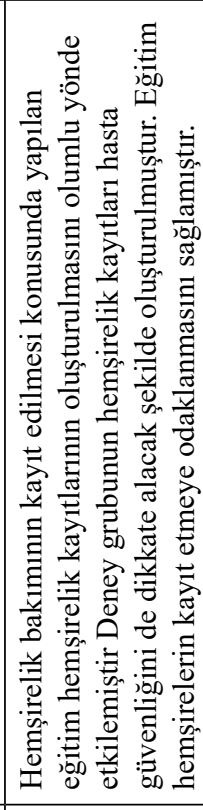 & 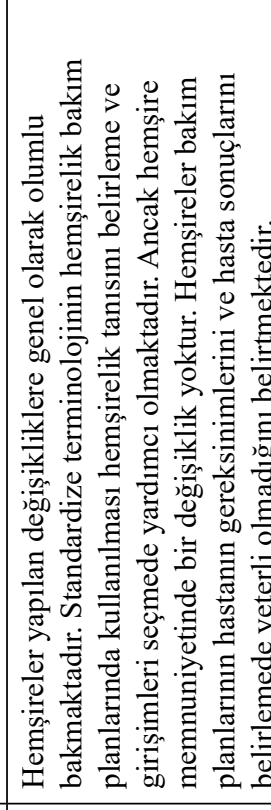 \\
\hline 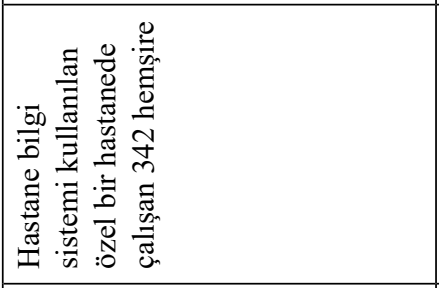 & 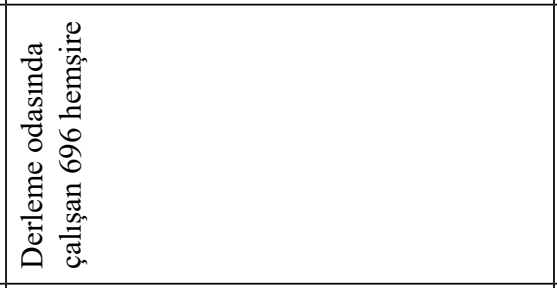 & 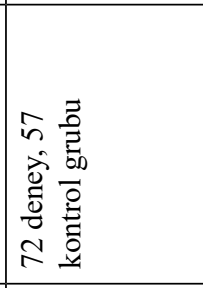 & 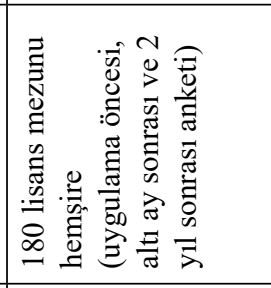 \\
\hline 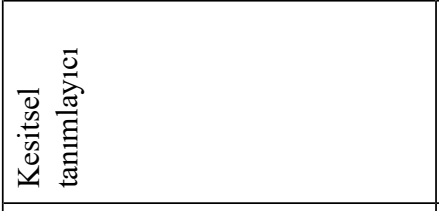 & 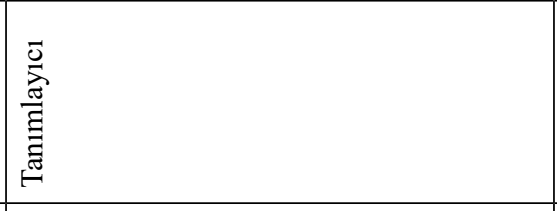 & 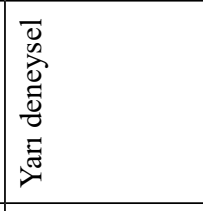 & 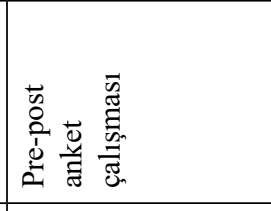 \\
\hline 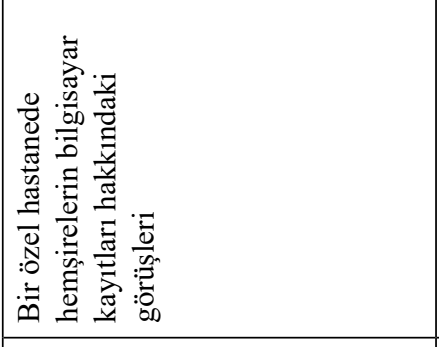 & 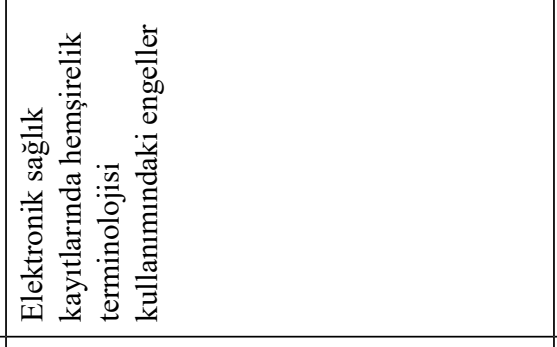 & 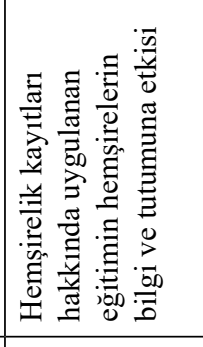 & 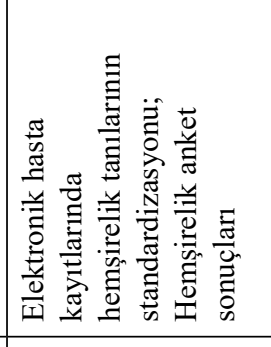 \\
\hline 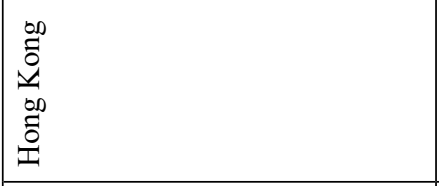 & 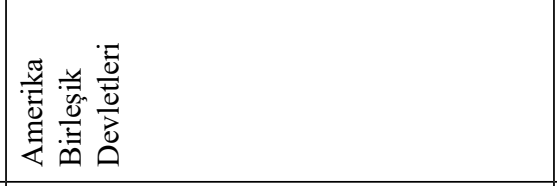 & 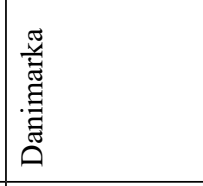 & 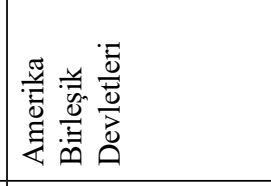 \\
\hline$\overline{\vec{~}}$ & $\stackrel{\sim}{\stackrel{\sim}{\sim}}$ & 蒿 & $\stackrel{\sim}{\stackrel{\sim}{\sim}}$ \\
\hline 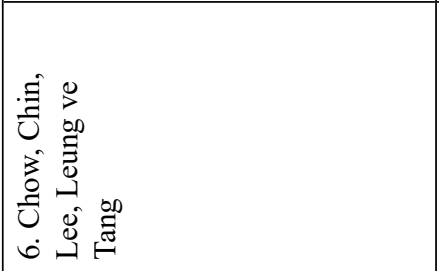 & 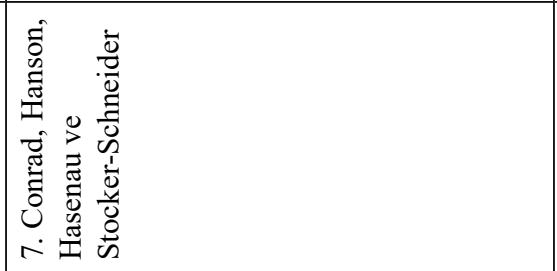 & 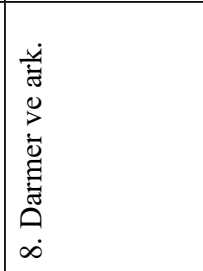 & 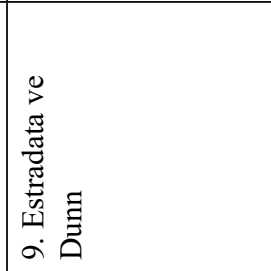 \\
\hline
\end{tabular}




\begin{tabular}{|c|c|c|c|c|}
\hline 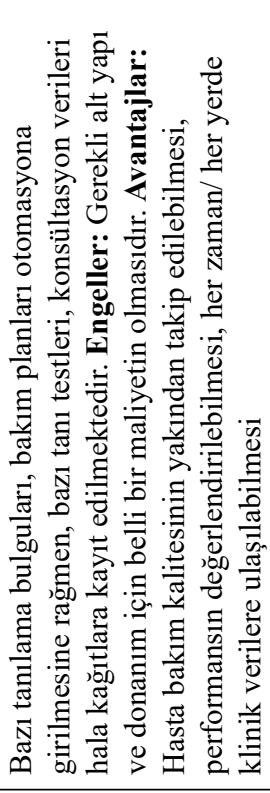 & 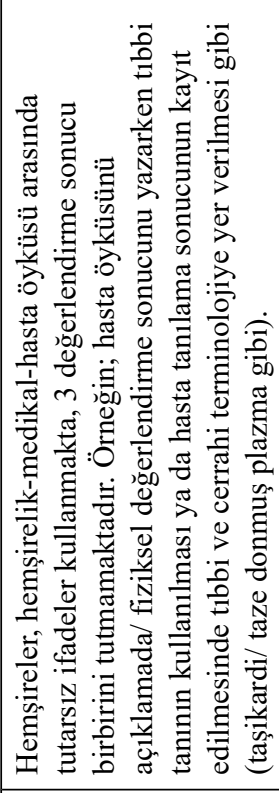 & 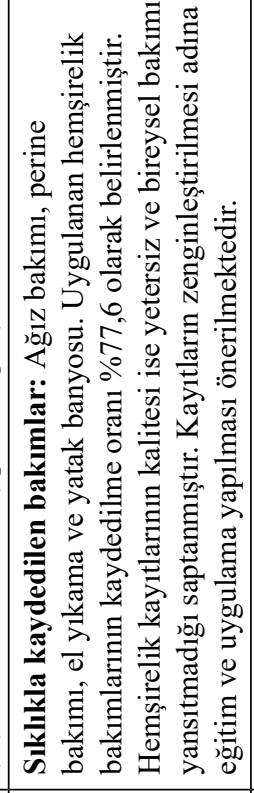 & 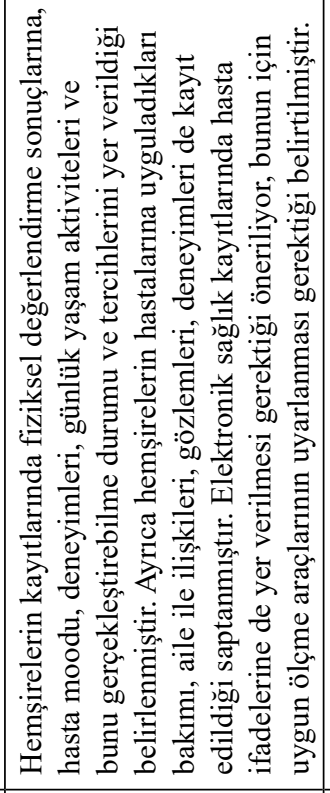 & 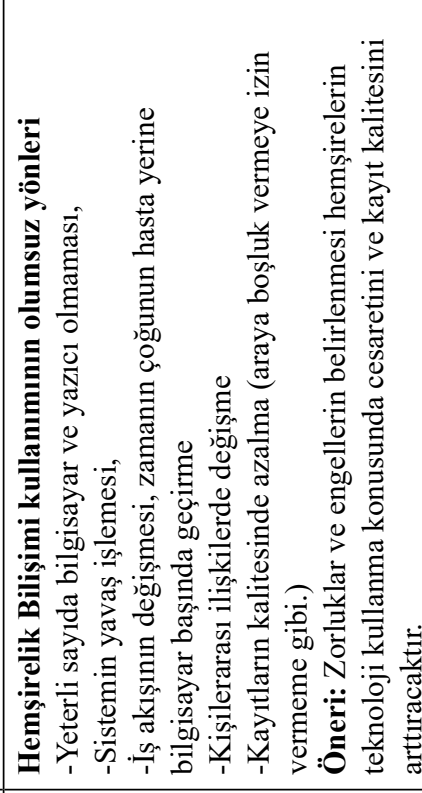 \\
\hline 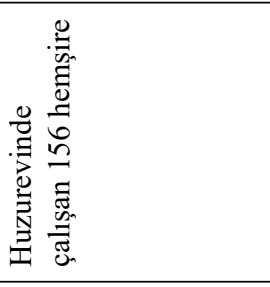 & 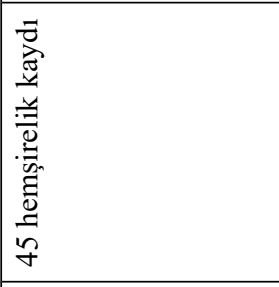 & 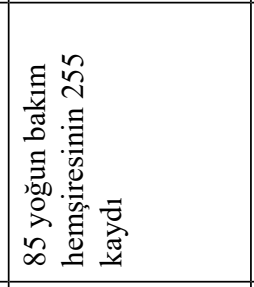 & 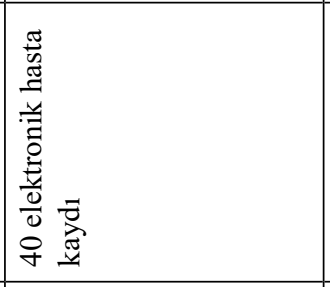 & 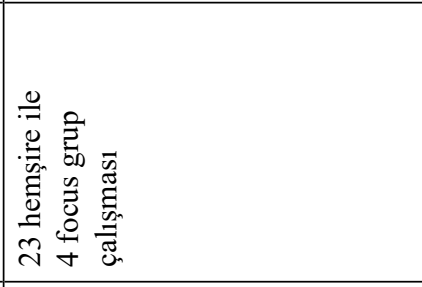 \\
\hline 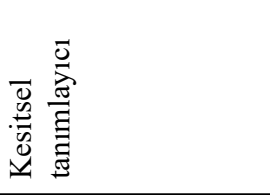 & 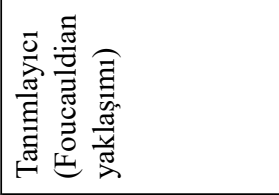 & 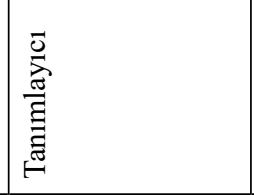 & 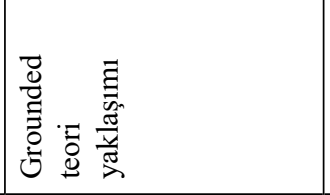 & 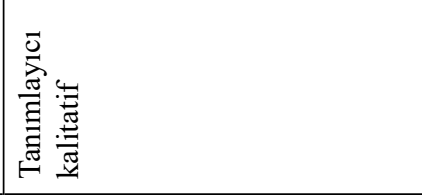 \\
\hline 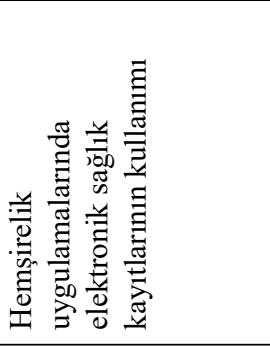 & 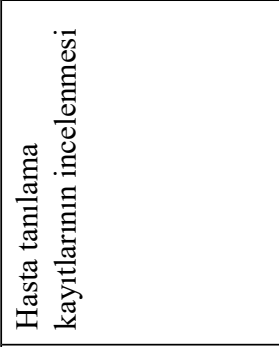 & 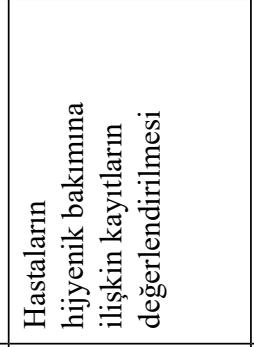 & 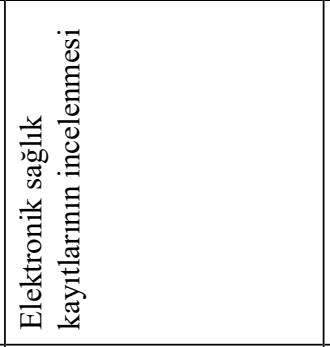 & 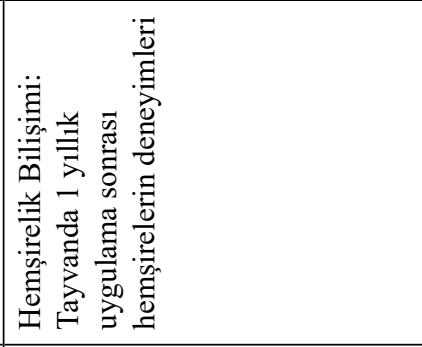 \\
\hline 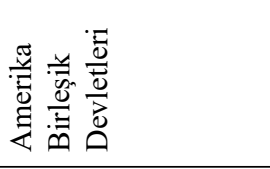 & 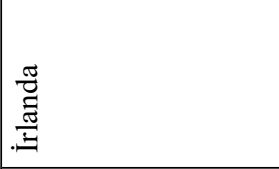 & 莡 & 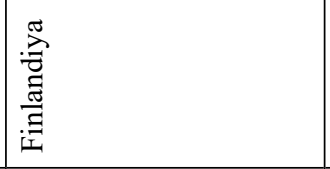 & 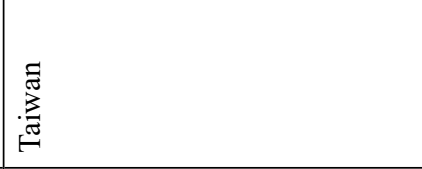 \\
\hline ב⿳亠े⿵冂丶 & ఫั & $\frac{m}{\vec{i}}$ & $\stackrel{\circ}{\stackrel{i}{d}}$ & 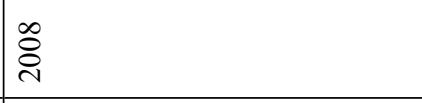 \\
\hline 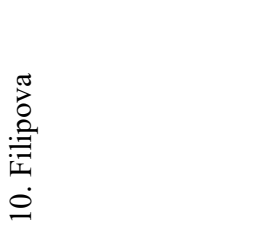 & 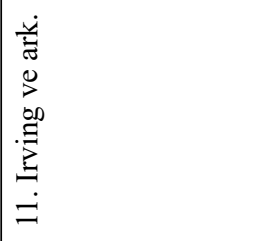 & 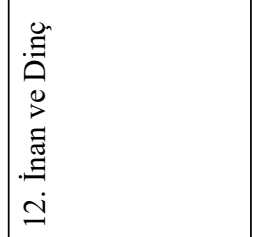 & 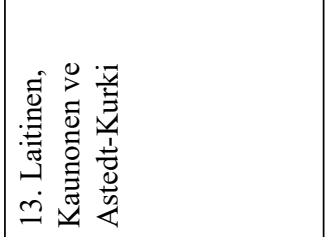 & \begin{tabular}{|l}
$\stackrel{\mathscr{J}}{\unlhd}$ \\
$\dot{\Xi}$
\end{tabular} \\
\hline
\end{tabular}




\begin{tabular}{|c|c|c|c|}
\hline 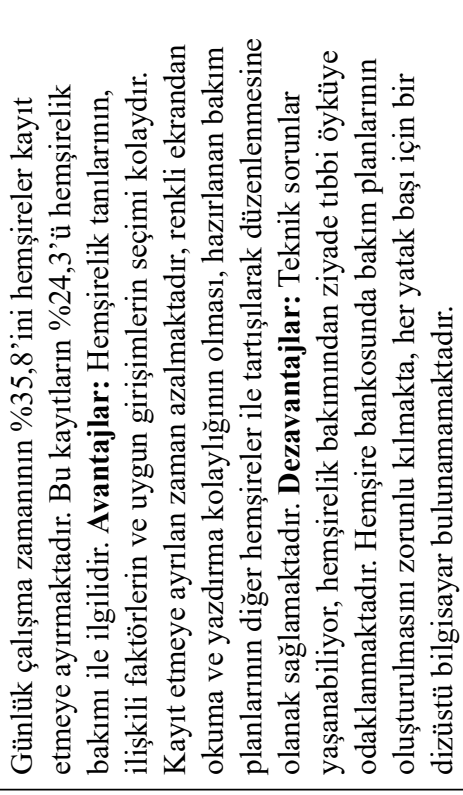 & 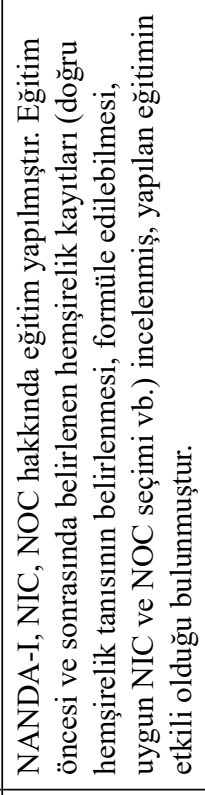 & 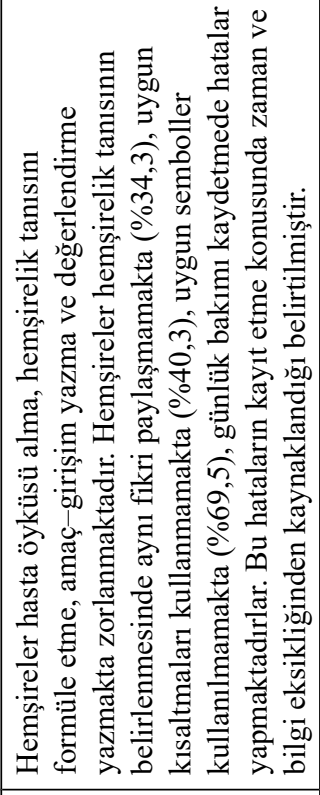 & 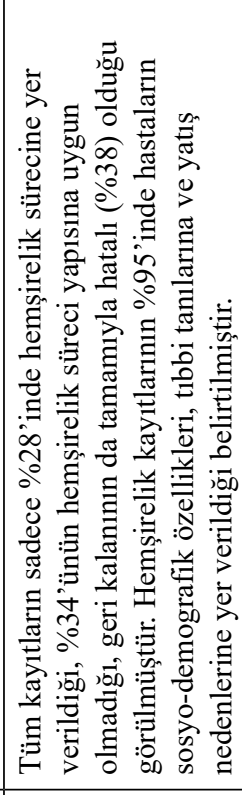 \\
\hline 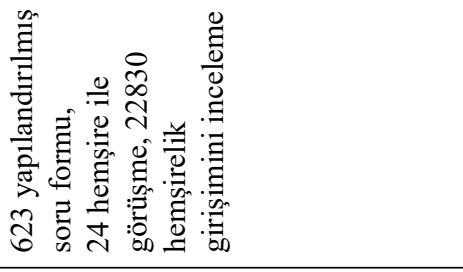 & 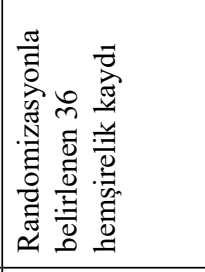 & 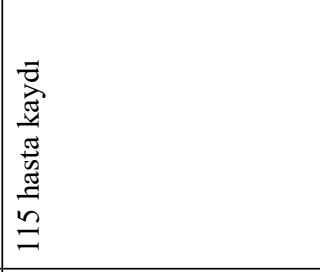 & 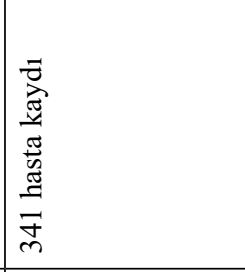 \\
\hline 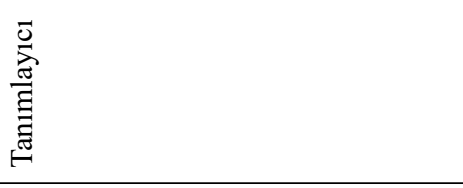 & 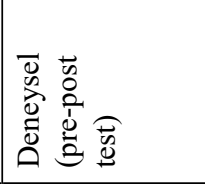 & 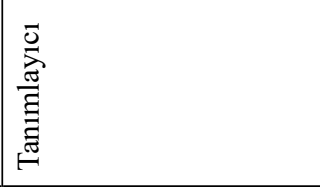 & 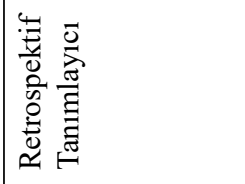 \\
\hline 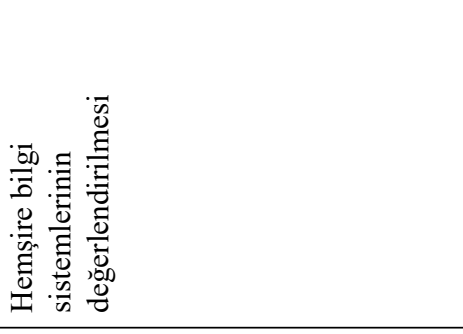 & 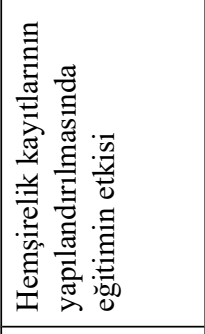 & 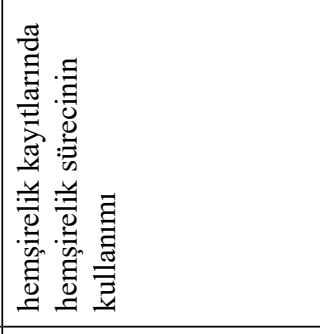 & 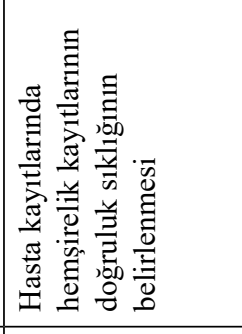 \\
\hline 胥 & 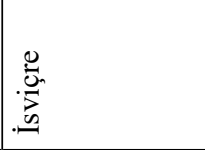 & 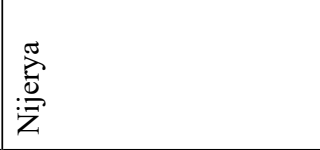 & 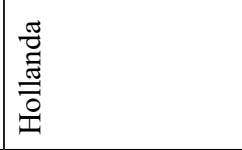 \\
\hline ڤ્ટે & 仓े & $\stackrel{\sim}{\stackrel{\sim}{\sim}}$ & $\stackrel{\circ}{\stackrel{2}{\sim}}$ \\
\hline 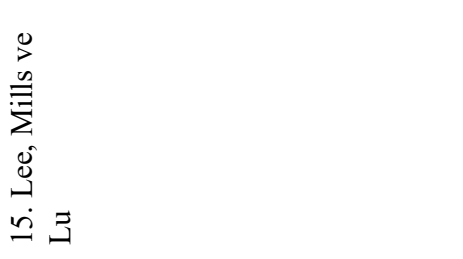 & 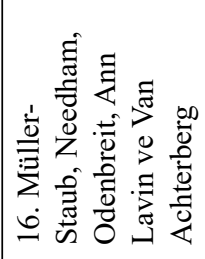 & 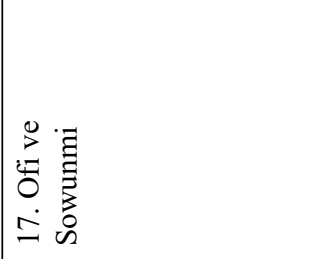 & 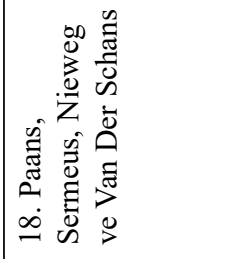 \\
\hline
\end{tabular}




\begin{tabular}{|c|c|c|}
\hline 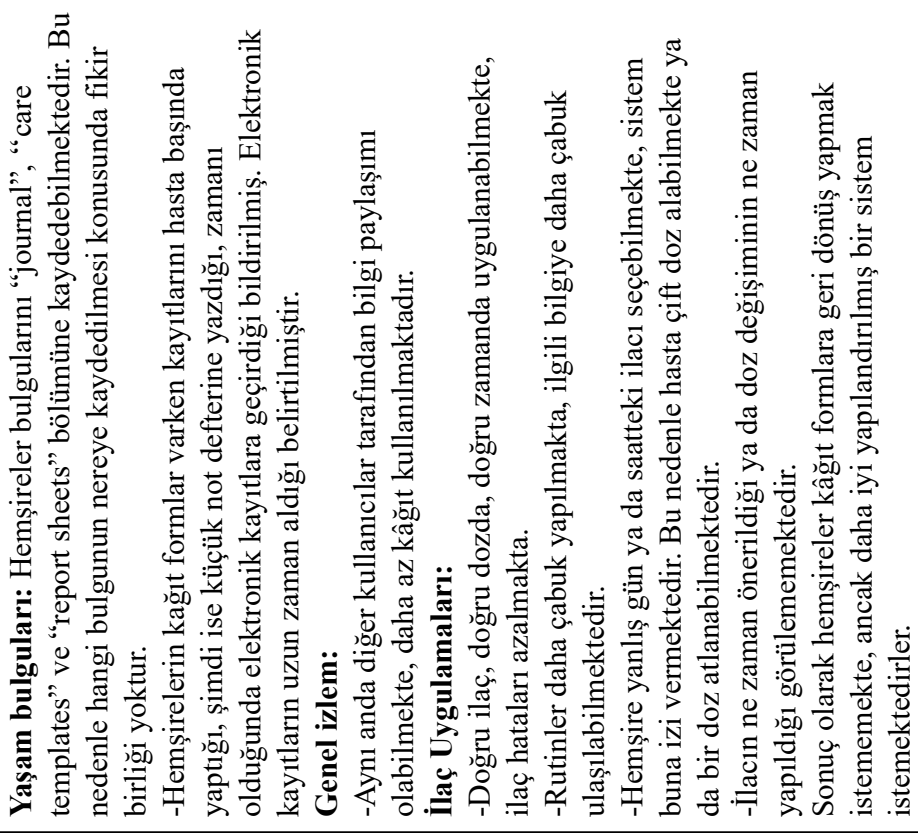 & 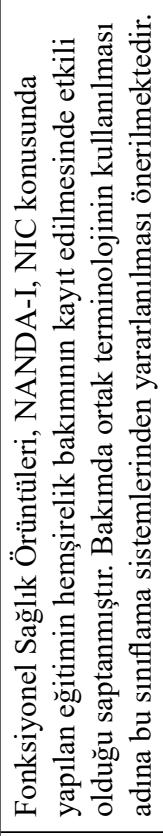 & 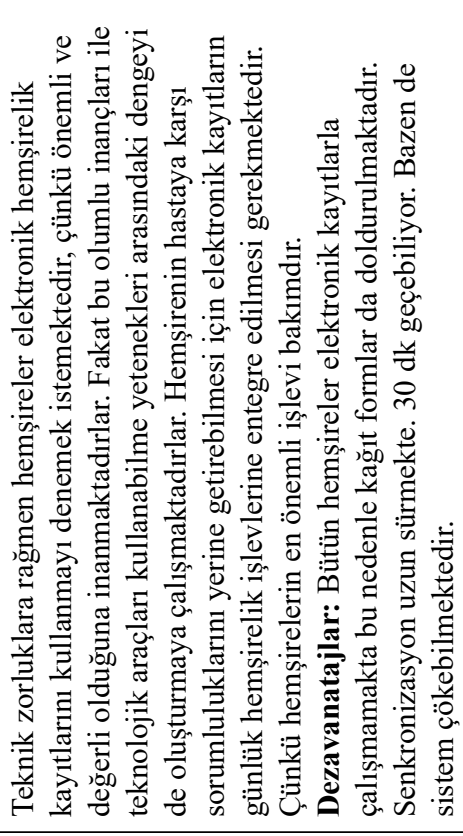 \\
\hline 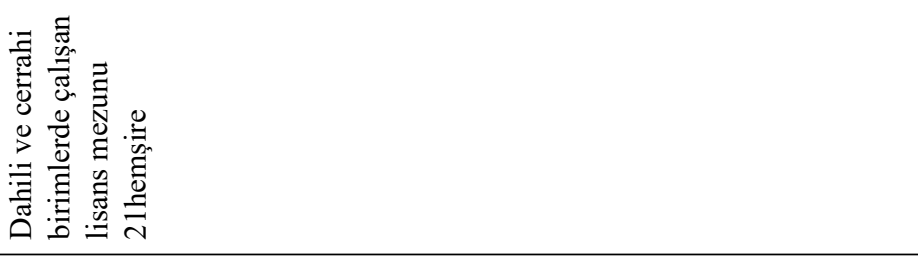 & 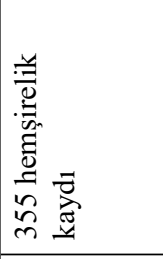 & 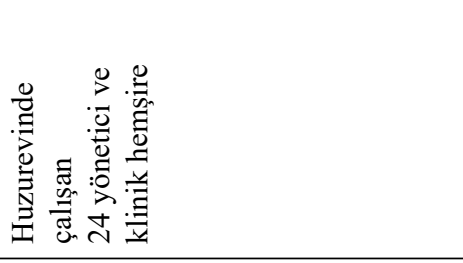 \\
\hline 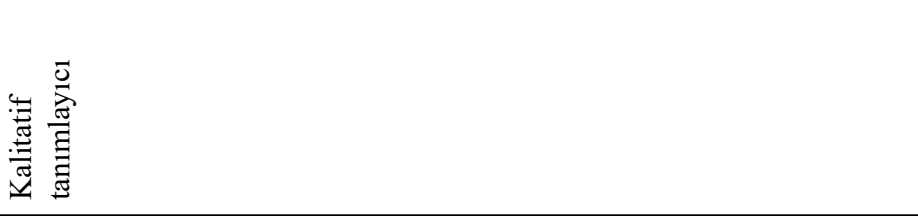 & 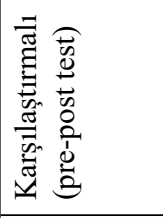 & 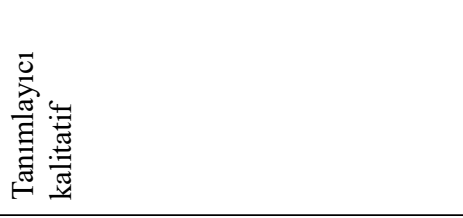 \\
\hline 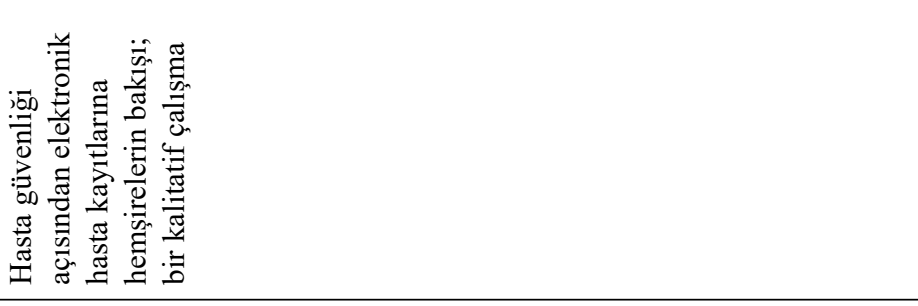 & 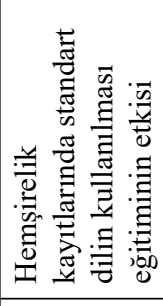 & 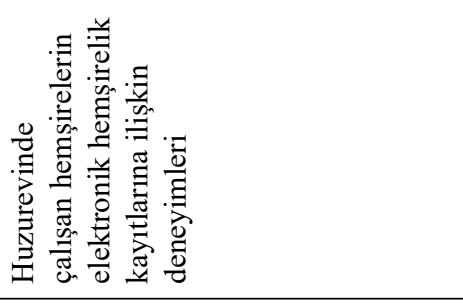 \\
\hline 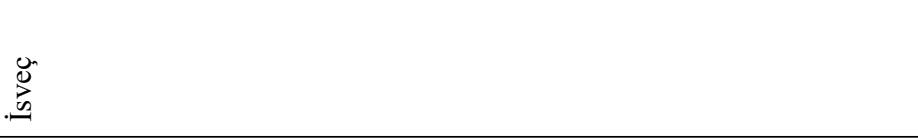 & 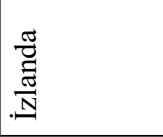 & $\begin{array}{l}\frac{\mathscr{J}}{\vec{d}} \\
\frac{\tilde{D}}{\mathscr{n}}\end{array}$ \\
\hline$\overline{\vec{\sim}}$ & $\hat{\stackrel{d}{0}}$ & $\stackrel{\circ}{\stackrel{i}{\sim}}$ \\
\hline 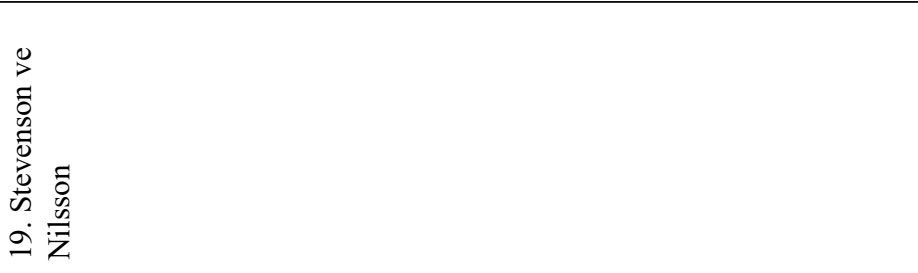 & 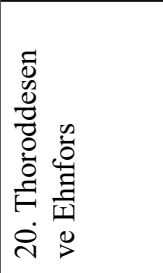 & 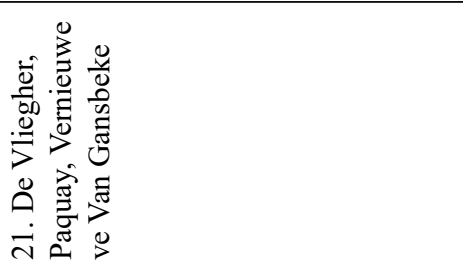 \\
\hline
\end{tabular}




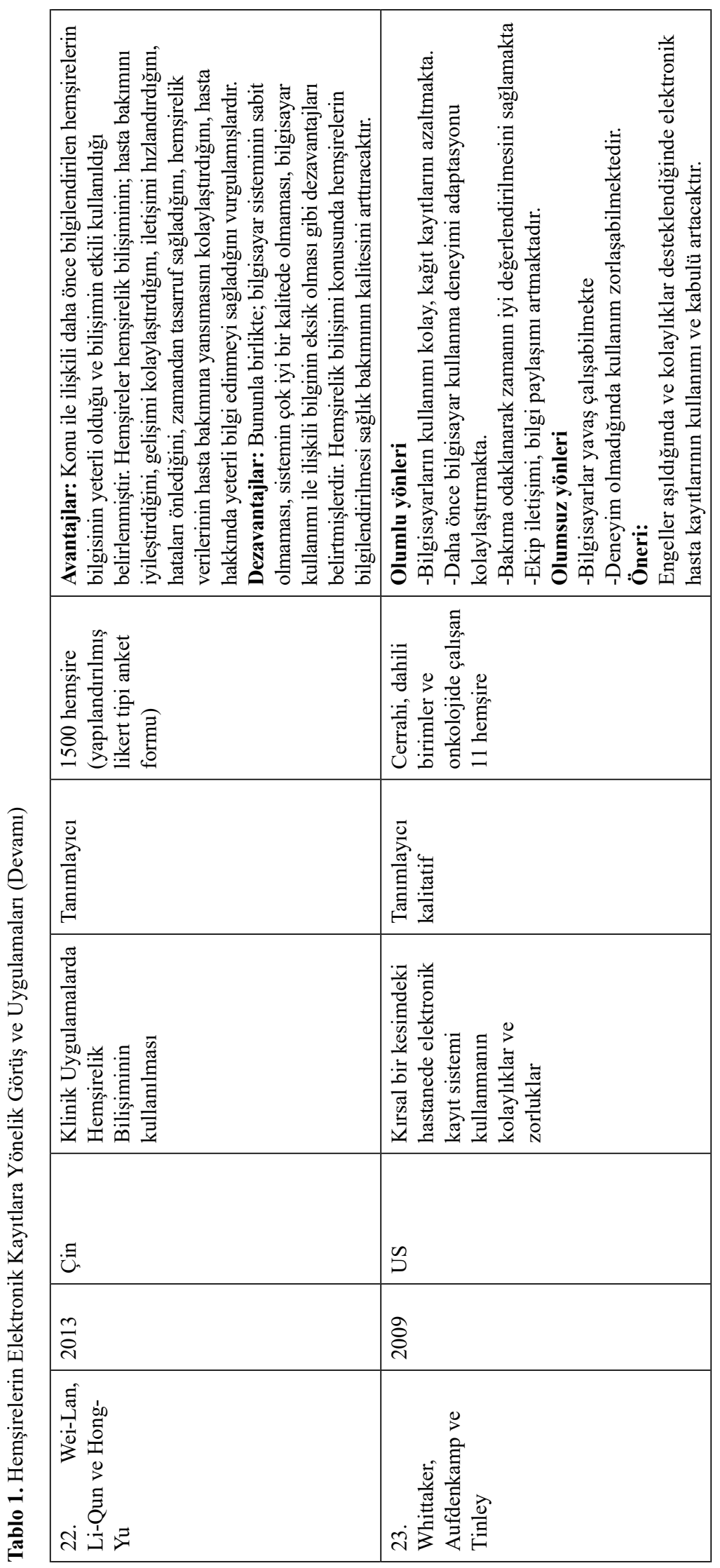

tanısını formüle etme, amaç-girişim yazma ve değerlendirmeyi yazmakta zorlandıkları, hemşirelik tanısının belirlenmesinde aynı fikri paylaşmadıkları $(\% 34,3)$, uygun kısaltmaları kullanmadıkları (\%40,3), uygun semboller kullanmadikları $(\% 69,5)$, günlük bakımı kaydetmede hatalar yaptıkları ve bu hataların kayıt etme konusunda zaman ve bilgi eksikliğinden kaynaklandığ dir. Thoroddesen ve Ehnfors (2007) ise; Fonksiyonel Sağlık Örüntüleri, NANDA-I, NIC konusunda yapılan eğitimin hemşirelik bakımının kayıt edilmesinde etkili olduğunu saptamışlardır. Bakımda ortak terminolojinin kullanılması adına bu sınıflama sistemlerinden yararlanılması gerektiği önerilmektedir (Tablo 1).

\section{TARTIŞMA}

Hemşirelik kayıtları hemşirelik bakımının önemli bir parçasını oluşturur. Sistemli yapılan tüm çalışmalar, düzenli kayıtlara temellenir. Eğer kayıt işlemi gerektiği gibi yapılmaz ise hemşirelik süreci başarılı olamaz. Yasal açıdan bir kanıt özelliği taşıyan hemşirelik kayıtları; sağlık bakım profesyonelleri arasındaki iletişimin sağlanmasına, hasta bakım planının oluşturmasına, hastanın sağlık durumunun kontrol edilmesine, araştırmalar ve eğitim için kaynak oluşturulmasına, sağlık harcamaları için geri ödemelerin belirlenmesine ve sağlık bakım kalitesinin analiz edilmesine olanak sağlar (Ionna, Stiliani ve Vasiliki 2007; Kelley, Brandon ve Docherty 2011; Prideaux 2011). Bunun için kayıtların doğru, kapsamlı, geçerli, 
organize olması ve bireyin gizliliğini sağlaması önem taşır (Acaroğlu, Şendir ve Kaya 2012; Wang, Hailey ve Yu 2011).

İncelenen çalışmalarda, hemşirelerin elektronik hemşirelik kayıtlarının önemine inandıkları, kayıtların hemşirelik bakım kalitesini arttırdığını düşündükleri; buna karşın hemşirelik kayıtlarında yazma/ raporlandırmayı ihmal ettikleri görülmektedir. Bunun en önemli nedenlerinin kayıtların yazımının kolay olmamas1, kayit etmeye yeterli zaman ayrilamamas1 ve ortak hemşirelik terminolojisi hakkında bilgi eksikliği olduğu belirtilmektedir (Tablo 1). Bu konu ile ilgili Cheevakasemsook, Chapman, Fracis ve Davies (2006) hemşirelik verilerinin çok fazla olması ve yazılı olarak organize bir şekilde kayıt edilmemesi nedeniyle elektronik ortama aktarılmasında zorluklar yaşandığını belirtmektedir. Bu duruma hemşirelerde bilgi eksikliğinin, motivasyon ve tutum eksikliğinin, etkisiz hemşirelik prosedürlerinin ve denetim eksikliğinin neden olduğu gösterilmektedir (Blair ve Smith 2012; Cheevakasemsook ve ark. 2006).

Tablo 1'de görüldüğü gibi incelenen çalı̧̧malarda hemşirelerin hasta öyküsü, hemşirelik tanısını formüle etme, amaç-girişim yazma ve değerlendirme yapmakta zorlandıkları; yaptıkları kayıtlarda siklıkla hastaların sosyo-demografik özelliklerine, tıbbi tanılarına, yatış nedenlerine ve uygulanan tedavi-bakımlarının kayıt edilmesine yer verdikleri görülmektedir. Benzer şekilde Törnvall ve Wilhelmsson (2008) hemşireler $(\mathrm{N}=554)$ ve hemşire yöneticiler $(\mathrm{N}=82)$ ile yaptıkları tanımlayıcı çalışmada elektronik ortamda bakımı kayıt etmek ve sonuçları değerlendirmek yerine klinik işleyiş ile değerlendirmelerin yapılmasında (enfeksiyon oranı, oral mukozit oranı vb.) kullanıldığını belirtmektedir. Ayrıca bu sistematik inceleme çalışmasında hemşirelerin elektronik bakım planlarının oluşturulmasına ilişkin sınıflama sisteminden yararlanmaya olumlu baktıkları, NANDA-I, NOC, NIC ve bu konuda yapılan eğitimlerin hemşirelik kayıtlarının yapılandırılmasında etkili olduğu vurgulanmaktadır (Tablo 1). Bu konu ile ilgili literatürde bakım ile ilgili elektronik kayıtların yapılandırılmasında hemşire görüşlerine yer verilmesi gerektiği, etkili ve güvenilir elektronik sağlık bakımı kayıtlarının sağlık sunumunu hızlandırdığı, maliyeti azalttığı, bireyin tanılama sürecini kısalttığ ve karar vermeyi kolaylaştırdığ belirtilmektedir (Ay 2009; Blair ve Smith 2012; Bilgiç ve Şendir 2014; Kelly ve ark. 2011).

\section{SONUÇ VE ÖNERILER}

$\mathrm{Bu}$ çalışma, etkili ve güvenilir elektronik hemşirelik kayıtlarının yapılandırılmasında ve bakım planlarının oluşturulmasında mevcut durumu ortaya koymaktadır. Sinıflama sistemlerinden yararlanılarak oluşturulacak elektronik hemşirelik bilişim sistemlerinde bu bulguların dikkate alınması ve sistemi kullanacak hemşirelere gerekli eğitimlerin planlanması önerilir.

\section{KAYNAKLAR}

Acaroğlu, R., Şendir, M., Kaya, H. (2012). Hemşirelik süreci. Babadağ, K., Atabek-Aşt1, T. (Eds.). Hemşirelik Esasları Uygulama Rehberi. İstanbul Medikal Sağlık ve Yayıncılık, İstanbul, 8-20.

Akın, Ö., Khorsid, L. (2006). Hemşirelik öğrencilerinin bilgisayar kullanmaya yönelik tutumlarının incelenmesi. Ege Üniversitesi Hemşirelik Yüksekokulu Dergisi, 22(1): 55-67.

Alquraini, H., Alhashem, A. M., Shah, M. A., Chowdhury, R. I. (2007). Factors influencing nurses' attitudes towards the use of computerized health information systems in Kuwaiti hospitals. Journal of Advanced Nursing, 57(4): 375-381.

Avoka-Asamani, J. A., Amenorpe, F. D., Babanawo, F., Ofei, A. M. A. (2014). Nursing documentation of inpatient care in Eastern Ghana. British Journal of Nursing, 23(1): 48-54.

Ay, F. (2009). Uluslararası elektronik hasta kayıt sistemleri, hemşirelik uygulamaları ve bilgisayar ilişkisi. Gülhane Tıp Dergisi, 51(2): 131-136.

Bilgiç, Ş., Şendir, M. (2014). Hemşirelik bilişimi. Cumhuriyet Hemşirelik Dergisi, 3(1): 24-28.

Blair, W., Smith, B. (2012). Nursing documentation: Frameworks and barriers. Contemporary Nurse, 41(2): 160-168.

Blake-Mowatt, C., Lindo, J. L. M., Bennett, J. (2013). Evaluation of registered nurses' knowledge and practice of documentation at a Jamaican hospital. International Nursing Review, 60(3): 328-334.

Broderick, M. C., Coffey, A. (2013). Person-centred care in nursing documentation. International Journal of Older People Nursing, 8(4): 309-318. 
Cheevakasemsook, A., Chapman, Y., Francis, K., Davies, C. (2006). The study of nursing documentation complexities. International Journal of Nursing Practice, 12(6): 366-374.

Cheng, Y. M. (2012). The effects of information systems quality on nurses' acceptance of the electronic learning system. Journal of Nursing Research, 20(1): 19-31.

Chow, S. K., Chin, W. Y., Lee, H. Y., Leung, H. C., Tang, F. H. (2012). Nurses' perceptions and attitudes towards computerisation in a private hospital. Journal of Clinical Nursing, 21(11-12): 1685-1696.

Conrad, D., Hanson, P. A., Hasenau, S. M., Stocker-Schneider, J. (2012). Identifying the barriers to use of standardized nursing language in the electronic health record by the ambulatory care nurse practitioner. Journal of the American Academy of Nurse Practitioners, 24(7): 443-451.

Darmer ve ark. (2004). The effect of a VIPS implementation programme on nurses' knowledge and attitudes towards documentation. Scandinavian Journal of Caring Sciences, 18(3): 325-332.

De Vliegher, K., Paquay, L., Vernieuwe, S., Van Gansbeke, H. (2010). The experience of home nurses with an electronic nursing health record. International Nursing Review, 57(4): 508-513.

Erdemir, F. (2007). Hemşirelik bilişimi eğitimi, http://www.turkmia.org/ (12.07.2014).

Erdoğan, S. (2003). Standart ve ortak dil kullanmak hemşireliğin geleceği için fırsat mı? ÏÜFNHYO Dergisi, 13(50): 1-13.

Estradata, N. A., Dunn, C. (2012). Standardized nursing diagnoses in an electonic health record: Nursing survey results. International Journal of Nursing Knowledge, 23(2): 86-94.

Filipova, A. A. (2013). Electronic health records use and barriers and benefits to use in skilled nursing facilities. Computers Informatics Nursing, 31(7): 305-318.

İnan, N. K., Dinç, L. (2013). Evaluation of nursing documentation on patient hygienic care. International Journal of Nursing Practice, 19(1): 81-87.

Ioanna, P., Stiliani, K., Vasiliki, B. (2007). Nursing documentation and recording systems of nursing care. Health Science Journal, 4(1): $38-45$.

Irving, K. ve ark. (2006). Discursive practices in the documentation of patient assessments. Journal of Advanced Nursing, 53(2): 151-159.

Kelley, T. F., Brandon, D. H., Docherty, S. L. (2011). Electronic nursing documentation as a strategy to improve quality of patient care. Journal of Nursing Scholarship, 43(2): 154-162.

Laitinen, H., Kaunonen, M., Astedt-Kurki, P. (2010). Patientfocused nursing documentation expressed by nurses. Journal of Clinical Nursing, 19(3-4): 489-497.
Lee, T. T. (2008). Nursing information: Users' experiences of a system in Taiwan one year after its implementation. Journal of Clinical Nursing, 17(6): 763-771.

Lee, T. T., Mills, M. E. E., Lu, M. H. (2009). The multimethod evaluation of a nursing information system in Taiwan. Computers Informatics Nursing, 27(4): 245-253.

Mutluay, E., Özdemir, L. (2014). Sağlık bilişim sistemleri kapsamında hemşirelik bilişiminin kullanımı. F.N. Hem. Derg, 22(3): 180-186.

Müller-Staub, M., Needham, I., Odenbreit, M., Ann-Lavin, M., Van Achterberg, T. (2007). Improved quality of nursing documentation: Results of a nursing diagnoses, interventions, and outcomes implementation study. International Journal of Nursing Terminologies and Classifications, 18(1): 5-17.

Ofi, B., Sowunmi, O. (2012). Nursing documentation: Experience of the use of the nursing process model in selected hospitals in Ibadan, Oyo state, Nigeria. International Journal of Nursing Practice, 18(4): 354-362.

Ömürbek, N., Altın, F. G. (2009). Sağlık bilişîm sistemlerinin uygulanmasına ilişkin bir araştırma: İzmir örneği. SDÜ Fen Edebiyat Fakültesi Sosyal Bilimler Dergisi, 19(1): 211-232.

Özkurt, A. (2003). Tıpta bir geliştirilmiş gerçeklik uygulaması ve başarıyı etkileyen faktörler. DEÜ Mühendislik Fakültesi Fen ve Mühendislik Dergisi, 5(3): 55-68.

Paans, W., Sermeus, W., Nieweg, R., Van Der Schans, C. P. (2010). Prevalence of accurate nursing documentation in patient records. Journal of Advanced Nursing, 66(11): 2481-2489.

Prideaux, A. (2011). Issues in nursing documentation and recordkeeping practice. British Journal of Nursing, 20(22): 1450-1454.

Secginli, S., Erdogan, S., Monsen, K. A. (2014). Attitudes of health professionals towards electronic health records in primary health care settings: A questionnaire survey. Informatics for Health and Social Care, 39(1): 15-32.

Stevenson, J. E., Nilsson, G. (2011). Nurses' perceptions of an electronic patient record from a patient safety perspective: A qualitative study. Journal of Advanced Nursing, 68(3): 667-676.

Thoroddsen, A., Ehnfors, M. (2007). Putting policy into practice: Preand posttests of implementing standardized languages for nursing documentation. Journal of Clinical Nursing, 16(10): 1826-1838.

Törnvall, E., Wilhelmsson, S. (2008). Nursing documentation for communicating and evaluating care. Journal of Clinical Nursing, 17(16): 2116-2124.

Turhan, K., Köse, A. (2006). Hemşirelerin Hemşirelik Bilişimi Hakkındaki Düşüncelerinin Değerlendirilmesi: Trabzon İline Ait Bir Çalışma. VII. Ulusal Tıp Bilişimi Kongresi, 14-17 Ekim, Mağusa. 
Wang, N., Hailey, D., Yu, P. (2011). Quality of nursing documentation and approaches to its evaluation: A mixed method systematic review. Journal of Advanced Nursing, 67(9): 1858-1875.

Wei-Lan, X., Li-Qun, Y., Hong-Yu, Z. (2013). Nursing informatics in clinical practice in China. Computers Informatics Nursing, 31(5): 214-218.
Whittaker, A. A., Aufdenkamp, M., Tinley, S. (2009). Barriers and facilitators to electronic documentation in a rural hospital. Journal of Nursing Scholarship, 41(3): 293-300. 